\title{
THE HYDROLYSIS OF ADENOSINE TRIPHOSPHATE BY HUMAN SPERMATOZOA
}

\author{
I. F. DURR, A. ABLA ANd A. MROUEH \\ Department of Biochemistry, American University of Beirut, \\ Beirut, Lebanon
}

(Received 27th April 1972, accepted 19th June 1972)

\begin{abstract}
Summary. Human spermatozoa contain an ATPase which is stimulated by sodium and potassium ions in the presence of magnesium ions. The hydrolysis of ATP is inhibited by ouabain, sodium fluoride and Triton. The presence of an active 5 '-nucleotidase in human spermatozoa is indicated by the accumulation of adenosine as the ultimate product of ATP hydrolysis.
\end{abstract}

The hydrolysis of ATP has been extensively studied in the spermatozoa of various animals (Nelson, 1954; Bishop, 1958; Tibbs, 1959; Uesugi \& Yamazoe, 1966), but not so far in man. This paper provides evidence for an ATPase in spermatozoa, which is stimulated by sodium and potassium ions $\left(\mathrm{Na}^{+}+\mathrm{K}^{+}\right)$in the presence of magnesium ions.

Semen was collected from healthy individuals and pooled. After liquefaction, sperm counts were determined by use of a Neubauer counting chamber as in the routine counting of red blood corpuscles. The semen was centrifuged at $900 \mathrm{~g}$ for $10 \mathrm{~min}$, and the pellet was washed twice with a phosphate-based buffer, $\mathrm{pH}$ $7 \cdot 4$ (Peterson \& Freund, 1968). The pellet was suspended in this buffer which contains the cations-sodium, potassium and magnesium. The spermatozoa maintained good motility (50 to $60 \%$ ) for $3 \mathrm{hr}$. Such spermatozoa metabolized glucose or fructose at two to four times the rate of those of the same batch kept in their own plasma (I. F. Durr, unpublished data).

The content of each incubation mixture is indicated in Tables 1 and 2. The incubation was at $37^{\circ} \mathrm{C}$ and uniform shaking was maintained throughout the incubation. Labelled $\left[\mathrm{U}-{ }^{14} \mathrm{C}\right] \mathrm{ATP}$ or $\left[\mathrm{U}_{-}{ }^{14} \mathrm{C}\right] \mathrm{AMP}$ were used as substrate. The reaction was terminated by immersing the tube in a boiling water bath for $1 \mathrm{~min}$. After centrifugation, $20 \mu \mathrm{l}$ of the supernatant solution was 'spotted' onto a Whatman No. 3 paper and subjected to ascending chromatography for $23 \mathrm{hr}$ at $21^{\circ}$ C. Solvent A consisted of n-butanol: formic acid: water, 77:13:10 by vol. (Markham \& Smith, 1949), and was used to separate adenosine and adenine. Authentic samples gave $R_{\mathrm{F}}$ values of 0.14 and 0.3 , respectively, the $R_{\mathrm{F}}$ value being the ratio of the distance between the starting line and the centre of the spot to the distance between the starting line and the solvent front. The other nucleotides of ATP did not move significantly. Solvent B consisted of nbutanol:glacial acetic acid: acetone:ammonia:water, $14: 16: 10: 1: 9$ by vol. (Hollinger, 1971) and was used to separate ATP, ADP and AMP. Authentic 
samples gave $R_{\mathrm{F}}$ values of $0 \cdot 11,0.28$ and 0.52 , respectively. Adenosine and adenine had an almost identical $R_{\mathrm{F}}$ value, $0 \cdot 67$, in this system. Authentic ATP, ADP, AMP, adenosine and adenine were 'spotted' onto the same paper on which the aliquot of the incubation mixture was 'spotted'. The UV-absorbing spots corresponding to those of the authentic samples were cut out, and placed in a vial for counting in a Packard scintillation counter having $85 \%$ efficiency for radioactive carbon compounds.

Text-figure 1 shows the rate of ATP hydrolysis as well as the formation of its

TABLE 1

CATION STIMULATION OF ATP HYDROLYSIS BY HUMAN SPERMATOZOA

\begin{tabular}{c|c|c|c}
\hline \multirow{2}{*}{$\begin{array}{c}\text { Time of } \\
\text { incubation (min) }\end{array}$} & \multicolumn{3}{|c}{ Adenosine formed (nmol) } \\
\cline { 2 - 4 } & $\mathrm{Mg}^{++}$ & $\left(\mathrm{Na}^{+}+K^{+}\right)$ & $\mathrm{Mg}^{++}+\left(\mathrm{Na}^{+}+K^{+}\right)$ \\
\hline 60 & 21 & $35 \cdot 8$ & $57 \cdot 7$ \\
90 & $33 \cdot 6$ & $54 \cdot 2$ & 93.7 \\
\hline
\end{tabular}

The incubation mixture contained $2.7 \times 10^{8}$ spermatozoa, $200 \mathrm{nmol}$ [U- ${ }^{14}$ C]ATP $\left(4 \cdot 8 \times 10^{5}\right.$ counts $\left./ \mathrm{min}\right), 180 \mu \mathrm{mol}$ of tris-HCl buffer, $\mathrm{pH} 7$, supplemented with cations as indicated. The final volume was $2.2 \mathrm{ml}$. Spermatozoa used in this experiment were washed and suspended in 0.1 $\mathrm{M}$-tris-HCl, $\mathrm{pH} \mathrm{7}$, and supplemented with cations where indicated.

TABLE 2

\begin{tabular}{llll} 
INHIBITION & OF ATP HYDROLYSIS BY & SODIUM \\
FLUORIDE & OR OUABAIN-TREATED & HUMAN \\
& \multicolumn{3}{c}{ SPERMATOZOA }
\end{tabular}

\begin{tabular}{c|r|c|c}
\hline \multirow{2}{*}{$\begin{array}{c}\text { Time of } \\
\text { incubation (min) }\end{array}$} & \multicolumn{3}{|c}{ Adenosine formed (nmol) } \\
\cline { 2 - 4 } & Control & Ouabain & NaF \\
\hline 30 & 9.87 & 2.98 & - \\
60 & 16.03 & 4.31 & $2 \cdot 67$ \\
90 & 27.58 & 5.08 & 4.59 \\
\hline
\end{tabular}

The incubation mixture contained $1 \times 10^{8}$ spermatozoa, $200 \mathrm{nmol}$ [U-14 $\mathrm{C}$ ]ATP $\left(1.9 \times 10^{5}\right.$ counts/min $)$, $1.8 \mathrm{ml}$ Peterson \& Freund buffer, $\mathrm{pH} 7.4$, in a final vol. of $2.1 \mathrm{ml}$. The concentrations of ouabain and sodium fluoride were 0.1 and $1.0 \mathrm{~mm}$, respectively.

A I.8-ml vol. Peterson \& Freund buffer contain 252 $\mu \mathrm{mol} \mathrm{NaCl}, 5.4 \mu \mathrm{mol}$ of each of $\mathrm{KGl}$ and $\mathrm{MgSO}_{4}, 7.6$ $\mu \mathrm{mol} \mathrm{Na}_{2} \mathrm{HPO}_{4}$ and $15 \cdot 3 \mu \mathrm{mol} \mathrm{NaH} \mathrm{PO}_{4}$.

metabolites. About $80 \%$ of ATP was hydrolysed in the first $20 \mathrm{~min}$. Analysis of radioactivity in the various metabolites showed that adenosine was the major product and that human spermatozoa apparently contain an active 5 '-nucleotidase. The presence of $3^{\prime}$-AMP did not affect the rate of adenosine formation from 5'-AMP. On the other hand, 5'-GMP inhibited the rate of 5'-AMP hydrolysis by $25 \%$, thereby indicating that the nucleotidase is specific to 5 'nucleotides but not specific to adenine nucleotides. Levin \& Bodansky (1966) 


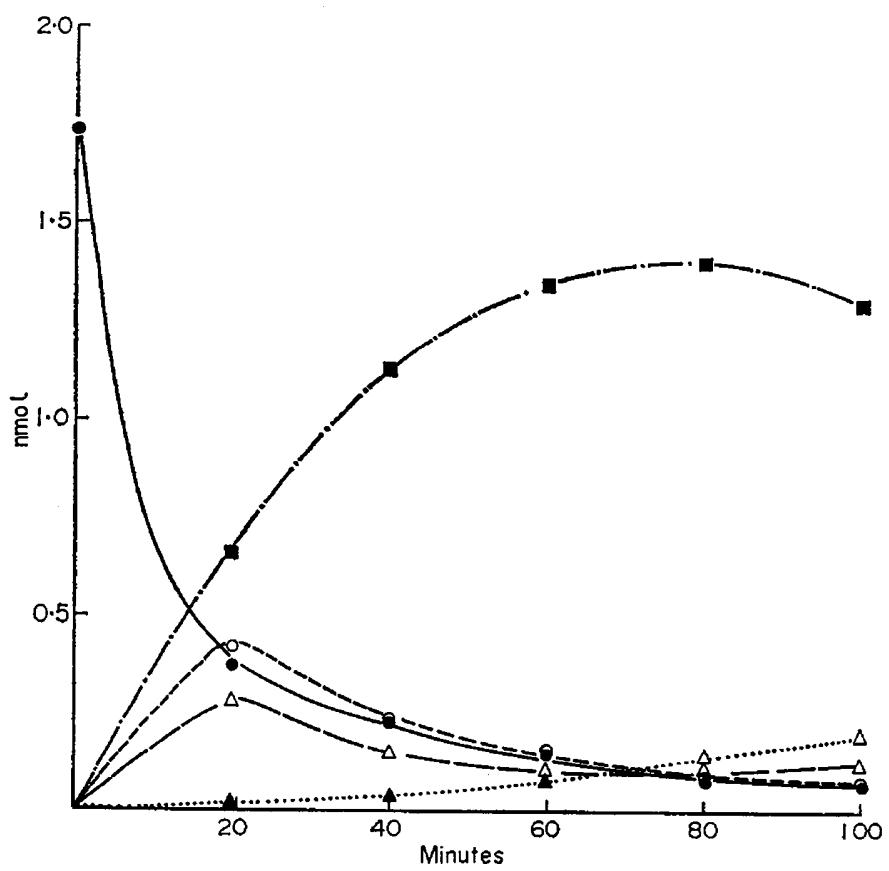
TEXT-FIG. 1. Rate of ATP hydrolysis and formation of various products $(\bullet, A T P ; O$,
ADP; $\triangle$ AMP; $\boldsymbol{Q}$, adenosine; $\Delta$, adenine). The incubation mixture contained $3.7 \times 10^{8}$ spermatozoa, $1.8 \mathrm{nmol}\left[\mathrm{U}-{ }^{14} \mathrm{C}\right]$ ATP $\left(1.16 \times 10^{6}\right.$ counts $\left./ \mathrm{min}\right)$ in a final vol. of $3 \mathrm{ml}$. At the indicated time intervals, aliquots were assayed for ${ }^{14} \mathrm{C}$ as described in a section of the text. A blank contained the same ingredients except that the spermatozoa were boiled for $3 \mathrm{~min}$.

TABLE 3

INHIBITION OF ATP HYDROLYSIS BY TRITONTREATED HUMAN SPERMATOZOA

\begin{tabular}{c|c|c}
\hline \multirow{2}{*}{$\begin{array}{c}\text { Time of } \\
\text { incubation }(\min )\end{array}$} & \multicolumn{2}{|c}{ Adenosine formed (nmol) } \\
\cline { 2 - 3 } & Control & Triton \\
\hline 30 & 49.5 & 19.2 \\
60 & 80.6 & 39.7 \\
90 & 117.2 & 58.6 \\
\hline
\end{tabular}

The incubation mixture contained $4.5 \times 10^{8}$ spermatozoa, $200 \mathrm{nmol}$ [U. $\left.{ }^{14} \mathrm{C}\right] \mathrm{ATP}\left(4.8 \times 10^{5}\right.$ counts $/ \mathrm{min}), 1.8 \mathrm{ml}$ Peterson \& Freund buffer, $\mathrm{pH} 7 \cdot 4$, in a final vol. of $2 \cdot 2 \mathrm{ml}$. The sperm suspension $(2 \mathrm{ml})$ was mixed with $0.2 \mathrm{ml}$ of $1 \% \mathrm{w} / \mathrm{v}$ Triton-X-100 in $\mathrm{H}_{2} \mathrm{O}$ for $5 \mathrm{~min}$ at room temperature. Subsequently, the spermatozoa were collected by centrifugation and suspended in Peterson \& Freund's buffer. 
described the properties of a $5^{\prime}$-nucleotidase isolated from bull seminal plasma. Further hydrolysis to adenine is a slow reaction. About $80 \%$ of the added ATP was recovered in adenosine. The remaining products, together with adenosine, quantitatively account for the added ATP. Addition of glucose, fructose, glucose-6-phosphate, fructose-6-phosphate, ribose or pyruvate did not significantly alter the pattern or rate of ATP metabolism. This is expected since the hexokinase and phosphofructokinase are rate-limiting, as shown by Peterson \& Freund (1970). In other systems, the hydrolysis of ATP produced equal amounts of ADP and AMP (Hollinger, 1971), or mainly ADP with some AMP (Quinn \& White, 1968). The rate of hydrolysis of $\left[\mathrm{U}^{14} \mathrm{C}\right] \mathrm{AMP}$ to adenosine was equal to the overall rate of hydrolysis of $\left[\mathrm{U}-{ }^{14} \mathrm{C}\right] \mathrm{ATP}$ to adenosine.

Since the major metabolite of ATP was adenosine, all subsequent assays involved measurement of $\left[{ }^{14} \mathrm{C}\right]$ adenosine. Table 1 shows that ATP hydrolysis is stimulated by $\left(\mathrm{Na}^{+}+\mathrm{K}^{+}\right)$in the presence of magnesium ions, which activate the enzyme involved in the transport of sodium and potassium ions. The observed hydrolysis of ATP may not be solely due to the $\left(\mathrm{Na}^{+}+\mathrm{K}^{+}\right)$-activated enzyme, since other ATPases may be present by analogy with other systems which also contain a magnesium-dependent ATPase (Bishop, 1958; Tibbs, 1959; Young \& Nelson, 1969).

O'Donnell \& Ellory (1970) showed that ouabain bound to bull spermatozoa, and that metabolic inhibitors such as sodium fluoride or detergents such as Triton decreased this binding. Consequently, the effect of such compounds on the hydrolysis of ATPase was investigated. The production of adenosine was determined at various time intervals ranging from 30 to $90 \mathrm{~min}$. Tables 2 and 3 show that the production of adenosine was severely inhibited. It should be noted that the release of adenosine is the result of more than one enzyme. Hence, the observed inhibition does not imply an inhibition of ATPase. Further, there was no correlation between changes in the numbers of motile spermatozoa with magnitudes of inhibition by ouabain, sodium fluoride and Triton.

\section{REFERENCES}

Bishop, D. W. (1958) Relaxing factor in ATP induced motility. Anat. Rec. 132, 414.

Hollinger, M. A. (1971) Metabolism of ATP by testis mitochondria of 25-day-old rats. F. Reprod. Fert. $25,443$.

Levin, S. J. \& Bodansky, O. (1966) The double pH optimum of 5 -nucleotidase of bull seminal plasma. 7. biol. Chem. 241, 51.

Markham, R. \& Smith, J. D. (1949) Chromatographic studies of nucleic acid. Biochem. 7. 45, 294.

Nelson, L. (1954) Enzyme distribution in fragmented bull spermatozoa. Biochim. biophys. Acta, $14,312$.

O'Donnell, J. M. \& Ellory, J. C. (1970) The binding of cardiac glycosides to bull spermatozoa. Experientia, 26, 20.

Peterson, R. N. \& Freund, M. (1968) An evaluation of the respiratory capacity of human spermatozoa. 7. Reprod. Fert. 17, 357.

Peterson, R. N. \& Freund, M. (1970) Profile of glycolytic enzyme activities in human spermatozoa. Fert. Steril. 21, 151.

Quins, P. J. \& White, I. G. (1968) Distribution of adenosine-triphosphatase activity in ram and bull spermatozoa. 7. Reprod. Fert. 15, 449.

TibBs, J. (1959) ATPase activity of perch sperm flagella. Biochim. biophys. Acta, 33, 220.

Uesugi, S. \& Yamazoe, S. (1966) Presence of sodium-potassium-stimulated ATPase in boar epididymal spermatozoon. Nature, Lond. 209, 403.

Young, I. G. \& Nelson, L. (1969) Divalent cation activation of flagellar ATP-phosphohydrolase from bull sperm. F. cell. comp. Physiol. 74, 315 . 